\title{
Effect of forty-four years of grazing on fescue grassland soils
}

\author{
JOHAN F. DORMAAR AND WALTER D. WILLMS
}

Authors are soil scientist and range ecologist, Research Centre, Agriculture and Agri-Food Canada, P. O. Box 3000, Lethbridge, Alberta, Canada T1J 4B1.

\begin{abstract}
A grazing study was initiated in the foothills of southwestern Alberta on the rough fescue grasslands (Festuca campestris (Rydb.) in 1949 comparing various grazing intensities. In 1992, soil samples were obtained from the Ah horizon of paddocks grazed at 1.2 (light), 2.4 (heavy), and 4.8 (very heavy) animal unit month ha-1 and from an ungrazed exclosure (control). The thickness of the Ah horizon of the control averaged $22 \mathrm{~cm}$ while that of the lightly, heavily and very heavily grazed paddocks averaged 18,12 , and $8 \mathrm{~cm}$, respectively. Soil color changed from 10YR 2/1 (black) to 10YR $4 / 3$ (dark brown to brown) in response to very heavy grazing. Grazing pressures decreased the mean-weight diameter of water-stable aggregates, total $\mathbf{C}$ and $\mathbf{P}$, monosaccharide content and the galactose + mannose/xylose + arabinose ratio, while it increased bulk density, $\mathrm{pH}-\mathrm{CaCl}_{2}$, and total $\mathrm{N}$. The loss of $P$ must be viewed with concern. Treatment effects on most soil parameters were most pronounced at the two heavier grazing pressures. Particularly, the heavy grazing pressure jeopardized the sustainability of the ecosystem by reducing fertility and water-holding capacity.
\end{abstract}

Key Words: soil quality, stocking rates, sustainability, phosphorus, monosaccharides, soil moisture, Ah ( $(=\mathrm{A1})$ horizon

The rough fescue grasslands (Festuca campestris (Rydb.) in western Canada are managed primarily for grazing by cattle. A study of the relationship of grazing intensity on the long-term carrying capacity of these grasslands was begun in 1949. By 1967 (Table 1), increasing grazing pressures led to a change of the colour of the Ah horizon from black to dark brown and of the $\mathrm{pH}$ from 5.7 to 6.2 (Johnston et al. 1971). Percent organic matter, percent total phosphorus and percent soil moisture decreased, while $\mathrm{NaHCO}_{3}$-soluble phosphorus and soil temperature increased. Trends indicated that soil of the very heavily grazed paddock was being transformed to a soil characteristic of a drier microclimate.

The sustainability of grazing use of the fescue grasslands may be assessed by change in a number of key soil indicators. Hence, it was opportune to re-examine the treatments, while still under the same grazing pressures, to follow through on the trends observed in 1967. This would allow a re-evaluation of some of the soil parameters measured in the earlier study, but also allow a more in-depth evaluation of other soil quality parameters.

\footnotetext{
The help of Bonnie Tovell and Rebecca Baldwin in carrying out the laboratory analyses is gratefully acknowledged.

Lethbridge Research Centre Contribution No. 3879675

Manuscript accepted 25 Feb. 1997.
}

\section{Resumen}

En 1949 se inició un estudio de pastoreo en praderas de Festuca (Festuca campestris) (Rydb.)) comparando diversas cargas de pastoreo, en las estribaciones montañosas del sudoeste de Alberta. En 1992, se obtuvieron muestras de suelo del horizonte Ah de los potreros que fueron pastoreados con una carga de 1.2 (liviana), 2.4 (intensa) y 4.8 (muy intensa) animales por mes y por hectárea y de 8 corral sin pastorear (control). El espesor del horizonte Ah de la parcela de control tuvo un promedio de $22 \mathrm{~cm}$ mientras que el de las parcelas de pastoreo en forma liviana, intensa y muy intensa promediaron 18,12 y $8 \mathrm{~cm}$, respectivamente. El color del suelo cambió de 10YR 2/1 (negro) a 10YR 4/3 (castaño oscuro a castaño) en la parcela intensamente pastoreada. La presión del pastoreo disminuyó el peso promedio del diámetro de los agregados de las aquas-estables, el total de $\mathbf{C}$ y $\mathbf{P}$, el contenido de monosacáridos y la proporción de la galactosa + manosa/xilosa + arabinosa, al mismo tiempo que incrementó la densidad volumétrica, el $\mathrm{pH}-\mathrm{C1}_{2} \mathrm{Ca}$ y el total de $\mathrm{N}$. Se debe de prestar una esmerada atención a la pérdida de $\mathrm{P}$. Los efectos del tratamiento en la mayoría de los parámetros del suelo fueron más evidentes en los 2 niveles de pastoreo más intensivos. En especial, la presión del pastoreo más intensivo puso en peligro la sustensión del ecosistema reduciendo la fertilidad y la capacidad de retener agua.

\section{Materials and Methods}

\section{Site Description}

The study area, located in the foothills of southwestern Alberta, $80 \mathrm{~km}$ northwest of Lethbridge, was established in 1949 under the auspices of Agriculture and Agri-Food Canada, Research Branch. It has been described previously (Johnston 1961; Johnston et al. 1971; Willms et al. 1985). The topography of the site is undulating, varying in elevation from 1,280 to $1,420 \mathrm{~m}$ above sea level. The climate is dry subhumid with a mean annual precipitation of $550 \mathrm{~mm}$. The soils are classified as Orthic Black Chernozemic (Udic Haploboroll) developed on till overlying sandstone (Dormaar et al. 1990a).

\section{Methods}

Paddocks were stocked at rates of 1.2 (light), 2.4 (heavy), and 4.8 (very heavy) animal unit month or AUM ha ${ }^{-1}$ since 1949 by stocking 13 cows and their calves on 65,32 and 16 ha, respectively, for 6 months from mid-May to mid-November (Willms et al. 1985). The recommended stocking rate for range in good condition in the area is 1.6 $\mathrm{AUM} \mathrm{ha}^{-1}$ (Wroe et al. 1981). 
Table 1. Characteristics of $A h$ horizon of soil from fields grazed at 4 rates for 17 years, Stavely, 1967 (averages of 10 samples ${ }^{\star}$ )(modified from Johnston et al. 1971).

\begin{tabular}{|c|c|c|c|c|c|c|c|c|}
\hline $\begin{array}{l}\text { Grazing } \\
\text { treatment }\end{array}$ & Color & $\begin{array}{c}\text { Soil } \\
\text { moisture }\end{array}$ & $\begin{array}{c}\text { Soil } \\
\text { temperature }\end{array}$ & $\begin{array}{c}\mathrm{pH} \\
\text { (water) }\end{array}$ & $\mathrm{OM}$ & $\mathbf{N}$ & $\begin{array}{c}\text { Total } \\
\mathbf{P}\end{array}$ & $\begin{array}{l}\mathrm{NaHCO}_{3}- \\
\text { Soluble P }\end{array}$ \\
\hline & (dry) & $(\%)$ & (C) & & $(\%)$ & $(\%)$ & $(\%)$ & $(\mu g / g)$ \\
\hline Light & $10 \mathrm{YR} 2 / 1$ & $40 \mathrm{a}$ & $13 a$ & $5.7 \mathrm{a}$ & $11.71 \mathrm{a}$ & $0.59 a$ & $0.111 \mathrm{a}$ & $2.9 \mathrm{a}$ \\
\hline Moderate & 10YR 3/1 & $37 \mathrm{ab}$ & $15 b$ & $5.8 \mathrm{a}$ & $11.23 \mathrm{a}$ & $0.60 \mathrm{a}$ & $0.107 a$ & $3.5 \mathrm{a}$ \\
\hline Heavy & 10YR $3 / 2$ & $31 \mathrm{~b}$ & $15 b$ & $6.0 \mathrm{ab}$ & $10.74 a$ & $0.63 a$ & $0.104 a$ & $3.5 \mathrm{a}$ \\
\hline Very heavy & $10 \mathrm{YR} 3 / 3$ & $24 c$ & $17 c$ & $6.2 b$ & $9.68 \mathrm{a}$ & $0.57 a$ & $0.099 \mathrm{a}$ & $4.0 \mathrm{a}$ \\
\hline
\end{tabular}

*Means followed by the same letter are not significantly different.

Soil samples were taken on 16 April, 14 May, 24 June, and 1 October, 1992, in the lightly, heavily, and very heavily grazed paddocks and in an ungrazed exlosure; however, not all analyses were carried out on samples taken on all these dates. Although Herrick and Whitford (1995) noted that spatial variability of many rangeland soil properties is extraordinarily high when compared with typical land under cultivation, it has been shown previously that the exclosures established in each of the 3 grazed paddocks yielded similar results (Dormaar et al. 1990a). Hence, the exclosure most centrally located to the 3 grazed paddocks was selected as the control. The Ah (=A1) soil horizons of the 3 grazed fields and the representative exclosure were sampled in 3 subplots. Moisture content was determined gravimetrically. The soils were dried and ground to pass a $0.5 \mathrm{~mm}$ sieve. After drying and grinding, the colors were rated according to the Munsell (1954) notation. Since the dry soil colours did not change over the season, the sampling data are omitted.

To examine root mass and root distribution, samples were taken with a golfcup-cutter $(10.4 \mathrm{~cm}$ diam. $\times 13 \mathrm{~cm}$ depth). The cores were initially soaked in pans of water and then gently rinsed. When the cores were saturated, they fell apart into lower soil with rootlets and upper soil with root mats. The depth of this root mat was measured. Undisturbed core samples, $55 \mathrm{~mm}$ diam. and $30 \mathrm{~mm}$ deep, were taken (16 April and 1 October) with a drop-hammer type sampler at 0- to 3-cm and 3- to 6-cm depths at each subplot. The cores were oven-dried, their mass obtained, and the bulk densities calculated.

Separate samples were obtained (16 April) for the determination of water-stable aggregates by passing them through an 8-mm sieve in the field. Following air-drying, water-stable aggregates that had been wetted by capillarity were obtained by the wet-sieving technique using the total soil sample. The mean-weight diameter was calculated to express the aggregate data in the form of a single parameter (Kemper and Rosenau 1986).

Soil $\mathrm{pH}$ was measured in $0.01 \mathrm{M} \mathrm{CaCl}_{2}$ (solution:soil ratio of 2:1). Total $\mathrm{C}$ and $\mathrm{N}$ were determined by dry combustion in a Carlo Erba NA 1500 Analyser. Nitrate-nitrogen $\left(\mathrm{NO}_{3}{ }^{-} \mathrm{N}\right)$ and $\mathrm{NH}_{4}{ }^{+}-\mathrm{N}$ were determined by $\mathrm{KCl}$ extraction and steam distillation as per Keeney and Nelson (1982). Total $P$ was determined as per $\mathrm{Na}_{2} \mathrm{CO}_{3}$ fusion outlined by Jackson (1958). $\mathrm{NaHCO}_{3}$-soluble phosphorus (available $\mathrm{P}$ ) was determined as described by Olsen et al. (1954). Neutral $\mathrm{NH}_{4} \mathrm{OAc}$ was used for the displacement of exchangeable cations (Simard 1993).

Acid hydrolysis was carried out essentially as outlined by Cheshire and Mundie (1966) and Cheshire (1979) except that the samples were first treated with $12 \mathrm{M} \mathrm{H}_{2} \mathrm{SO}_{4}$ for 16 hours at room temperature, then diluted to $0.5 \mathrm{M} \mathrm{H}_{2} \mathrm{SO}_{4}$ and held at $100^{\circ} \mathrm{C}$ for 1 hour (Dormaar 1984). Monosaccharides were reduced and acetylated as described by Blakeney et al. (1983). D-allose was added as the internal standard. The alditol acetates were identified with a Hewlett Packard GC 5840A equipped with a hydrogen flame ionization detector and a $30-\mathrm{m}$ long glass capillary column $(0.25 \mathrm{~mm}$ id.) wall-coated with OV-225 (50\% cyanopropyl$50 \%$ methylphenylpolysiloxane) with helium as the carrier gas at a linear flow rate of $21 \mathrm{~cm} \mathrm{sec}^{-1}$. Reference alditol acetates of rhamnose, fucose, ribose, arabinose, xylose, allose, mannose, galactose, and glucose were used as standards and prepared as outlined by Blakeney et al. (1983). Polysaccharides are considered to have a plant origin if they contain substantial quantities of arabinose and xylose and predominantly of microbial origin if they contain mainly galactose and mannose (Cheshire 1979).

In this unreplicated study, the sampling error was assumed to represent the experimental error and analyzed as a one-way analysis of variance. Single degree of freedom contrasts (Steel and Torrie 1980) were used to test for differences between selected means. Although replicated field plot experiments are desireable and useful, valid information can still be gained from early established, unreplicated field experiments including long-term grazing trials, by virtue of their antiquity (Ridley and Hedlin 1968, Dormaar and Pittman 1980, Dormaar and Willms 1990).

\section{Results and Discussion}

Rangeland soils present unique challenges and opportunities for assessing soil quality (Herrick and Whitford 1995). That is, grazing activity over an extended period of time will produce trends of altered soil properties (Table 2), that can be studied with repeated sampling. This study represents the second sampling period 25 years after the first one (Johnston et al. 1971) on paddocks having fixed stocking rates. At least some constituents were common which can be used to define trends. It should be noted that the results are only applicable for fescue or an equivalent type of grassland, since in mixed prairie (Smoliak et al. 1972) differences in amounts and kinds of roots occur.

In the comparison of light with very heavy stocking, the depth of the Ah horizon changed from about $22 \mathrm{~cm}$ to about $7.5 \mathrm{~cm}$. This may be the result of increased bulk density due to increased grazing pressure. Water and wind erosion cannot be discounted as causes for the Ah horizon depletion since Naeth (1988) reported that bare ground increased from zero to $15 \%$ on very heavily grazed range. Thatch was no longer present on the very heavily grazed paddock. As grazing pressure increased, roots became more concentrated in the upper part of the core with less distribution in the lower part, while roots in the cores obtained from the control paddock were distributed throughout the $13 \mathrm{~cm}$ core depth.

It has been shown elsewhere (Dormaar and Willms 1990) that under increased grazing pressure rough fescue was replaced by Parry oat grass (Danthonia parryi Scribn.), Idaho fescue (Festuca 
idahoensis Elmer), wheat grass (Agropyron spp.), and June grass [Koeleria cristata (L.) Pers.]. Prolonged heavy grazing pressure further resulted in a cover of weedy species, including pasture sage (Artemisia frigida Willd.), locoweed [Oxotropis campestris (1.) DC.], pussy-toes (Antennaria spp.), and dandelion (Taraxacum officinale Weber).

The color of the Ah horizon soil of the lightly grazed paddock had not changed between 1967 (Johnston et al. 1971) and 1992 (Table 1 vs Table 2), but in the same time period the soil color of the Ah horizon of the heavily grazed paddock changed from very dark grayish brown (10YR 3/2) to dark brown (10YR 3/3), while that of the very heavily grazed paddock changed from dark brown (10YR 3/3) to dark brown to brown (10YR 4/3). This can be attributed to either decreased organic matter input into the Ah horizon, or the upper part of the B horizon slowly being incorporated into the Ah horizon due to erosional loss of Ah horizon soil, or both.

Regardless of time of sampling and even though a significant $(P<0.05)$ interaction between time of sampling $X$ fields existed for most chemical constituants (Table 2), soil moisture content in the very heavily grazed paddock was always less than that in the control particularly during the April and May sampling. As well, the mean-weight diameter of the water-stable aggregates decreased from the control and the lightly grazed paddock to the heavily and very heavily grazed paddocks. With less thatch, root ramification, vegetative cover, soil moisture, and smaller soil aggregates, the soil of the very heavily grazed paddock is not only susceptible to water erosion, but to wind erosion as well. Except for the difference between the control and very heavily grazed paddock soils, all differences in bulk density between grazing treatments at both depths ( 0 to 3 and 3 to $6 \mathrm{~cm}$ ) were significant in both spring and autumn. Increased bulk density with increased grazing pressure exacerbates the potential for erosion and, with increased excreta load, down stream pollution.

Since the methods of analysis used in 1967 were different from those in 1992, direct numerical comparisons between the results may not be reasonable. Nevertheless, it is possible to compare the trends for some constituents. The $\mathrm{pH}$ did not vary much over the season, hence only the values of the 16 April samples are presented. The increase in $\mathrm{pH}$ is an indicator of soil loss, since with increased grazing pressure the depth of the soil profile decreased resulting in carbonates being closer to the surface.

Soil C content was significantly higher in the control and lightly grazed compared to the heavily and very heavily grazed paddocks. As grazing pressure increased, the $\mathbf{N}$ content increased when expressed as percent $N$ (compare Dormaar et al. 1990a). Of course, since total soil $\mathrm{C}$ decreased, the $\mathrm{C} / \mathrm{N}$ ratio decreased.

It has been shown that $\mathrm{NH}_{4}{ }^{+}-\mathrm{N}$ aids root ramification and

Table 2. Characteristics of Ah horizon of soil from fields grazed at 4 rates for 42 years, Stavely, 1992 (averages of 3 samples taken 16 April unless otherwise indicated).

\begin{tabular}{|c|c|c|c|c|c|c|c|c|c|c|c|c|}
\hline \multirow{3}{*}{$\begin{array}{l}\text { Grazing intensity }\left(\mathrm{AUM} / \mathrm{ha}^{-1}\right) \\
\text { Depth Ah horizon (cm) } \\
\text { Thatch (cm) } \\
\text { Rootmat (cm) }\end{array}$} & \multirow{2}{*}{\multicolumn{2}{|c|}{$\begin{array}{c}0.0 \\
(\mathrm{E})^{1} \\
20-24 \\
6-7\end{array}$}} & \multirow{3}{*}{$\begin{array}{l}1.2 \\
(\mathrm{~L}) \\
16-21 \\
4-5 \\
8-10\end{array}$} & \multirow{3}{*}{$\begin{array}{c}2.4 \\
(\mathrm{H}) \\
10-14 \\
4 \\
4-6\end{array}$} & \multirow{3}{*}{$\begin{array}{c}4.8 \\
(\mathrm{VH}) \\
6-9 \\
0 \\
3-4\end{array}$} & \multirow{2}{*}{\multicolumn{7}{|c|}{ Contrasts }} \\
\hline & & & & & & & & & & & & \\
\hline & & None per se & & & & E vs L & E vs H & E vs VH & L vs $\mathbf{H}$ & L vs VH & \multicolumn{2}{|c|}{$\begin{array}{c}\text { Date } \\
\mathrm{H} \times \text { field }\end{array}$} \\
\hline Color (dry - 10YR) & & $2 / 1$ & $2 / 1$ & $3 / 3$ & $4 / 3$ & & & & & & & \\
\hline Moisture (\%) & 16 Apr & 76 & 71 & 48 & 26 & 0.071 & $<0.001$ & $<0.001$ & $<0.001$ & $<0.001$ & $<0.001$ & \\
\hline & 14 May & 41 & 37 & 26 & 14 & 0.071 & $<0.001$ & $<0.001$ & $<0.001$ & $<0.001$ & $<0.000$ & $<0.001$ \\
\hline & 24 Jun & 60 & 49 & 43 & 40 & 0.001 & $<0.001$ & $<0.001$ & 0.029 & 0.003 & 0.179 & \\
\hline & 1 Oct & 57 & 54 & 54 & 36 & 0.215 & 0.312 & $<0.001$ & 0.794 & $<0.001$ & $<0.001$ & \\
\hline Bulk density $\left(\mathrm{Mg} \mathrm{m}^{-3}\right)-0-3 \mathrm{~cm}$ & $\begin{array}{r}16 \mathrm{Apr} \\
1 \mathrm{Oct}\end{array}$ & $\begin{array}{l}0.44 \\
0.48\end{array}$ & $\begin{array}{c}0.47 \\
0.48\end{array}$ & $\begin{array}{c}0.71 \\
0.75\end{array}$ & $\left.\begin{array}{l}0.76 \\
0.81\end{array}\right\}$ & 0.540 & $<0.001$ & $<0.001$ & $<0.001$ & $<0.001$ & 0.036 & NS \\
\hline$-3-6 \mathrm{~cm}$ & $\begin{array}{r}16 \mathrm{Apr} \\
1 \mathrm{Oct}\end{array}$ & $\begin{array}{l}0.60 \\
0.66\end{array}$ & $\begin{array}{l}0.67 \\
0.67\end{array}$ & $\begin{array}{l}0.83 \\
0.88\end{array}$ & $\left.\begin{array}{l}0.84 \\
0.87\end{array}\right\}$ & 0.140 & $<0.001$ & $<0.001$ & $<0.001$ & $<0.001$ & 0.953 & NS \\
\hline $\begin{array}{l}\text { Water-stable aggregate } \\
\text { MWD (mm) }\end{array}$ & & 1.69 & 1.64 & 1.43 & 1.35 & 0.515 & 0.007 & 0.002 & 0.020 & 0.004 & 0.290 & \\
\hline $\mathrm{pH} \mathrm{CaCl} 2$ & & 5.5 & 5.6 & 5.9 & 6.4 & 0.211 & 0.005 & $<0.001$ & 0.040 & $<0.001$ & 0.005 & \\
\hline Total C (\%) & & 11.4 & 11.0 & 8.5 & 7.5 & 0.220 & $<0.001$ & $<0.001$ & $<0.001$ & $<0.001$ & 0.013 & \\
\hline Total N (\%) & & 0.85 & 0.87 & 0.96 & 1.05 & 0.594 & 0.007 & $<0.001$ & 0.017 & $<0.001$ & 0.012 & \\
\hline $\mathrm{C} / \mathrm{N}$ & & 13.4 & 12.6 & 8.9 & 7.1 & & & & & & & \\
\hline \multicolumn{13}{|l|}{ Exchangeable N (mg/kg) } \\
\hline$-\mathrm{NH}^{+}$ & $16 \mathrm{Apr}$ & 35.4 & 23.4 & 16.8 & 11.5 & $<0.001$ & $<0.001$ & $<0.001$ & 0.022 & $<0.001$ & $0.052\}$ & $<0.001$ \\
\hline & $10 c t$ & 13.0 & 15.8 & 24.4 & 28.2 & 0.379 & 0.005 & $<0.001$ & 0.020 & 0.003 & 0.233 & \\
\hline$-\mathrm{NO}_{3}^{-}-\mathrm{N}$ & $16 \mathrm{Apr}$ & 2.9 & 5.6 & 5.5 & 8.4 & 0.017 & 0.019 & $<0.001$ & 0.942 & 0.014 & 0.013 & 0.003 \\
\hline & $10 \mathrm{Oct}$ & 3.2 & 4.9 & 5.2 & 13.3 & 0.163 & 0.107 & $<0.001$ & 0.789 & $<0.001$ & $<0.001\}$ & \\
\hline Total P (\%) & & 0.112 & 0.103 & 0.102 & 0.095 & 0.015 & 0.009 & $<0.001$ & 0.732 & 0.026 & 0.046 & \\
\hline $\begin{array}{l}\text { Available } \mathrm{P}\left(\mathrm{mg} . \mathrm{kg}^{-1}\right) \\
\mathrm{NH}_{4} \mathrm{OAc}- \\
\text { Extractable cations }(\%)\end{array}$ & & 4.0 & 4.3 & 5.3 & 5.2 & 0.517 & 0.012 & 0.020 & 0.035 & 0.059 & 0.743 & \\
\hline $\mathrm{Ca}$ & & 0.035 & 0.033 & 0.034 & 0.035 & 0.147 & 0.285 & 0.824 & 0.659 & 0.206 & 0.784 & \\
\hline $\mathrm{Mg}$ & & 0.066 & 0.063 & 0.065 & 0.066 & 0.457 & 0.925 & 0.850 & 0.514 & 0.358 & 0.777 & \\
\hline $\mathrm{Na}$ & & 0.019 & 0.046 & 0.056 & 0.085 & $>0.001$ & $<0.001$ & $<0.001$ & $<0.001$ & $<0.001$ & $<0.001$ & \\
\hline $\mathbf{K}$ & & 0.067 & 0.071 & 0.096 & 0.112 & 0.512 & 0.001 & $<0.001$ & 0.003 & $<0.001$ & 0.025 & \\
\hline Monosaccharides & $16 \mathrm{Apr}$ & 32.16 & 29.43 & 21.96 & 17.15 & 0.029 & $<0.001$ & $<0.001$ & $<0.001$ & $<0.001$ & 0.002 ) & $<0.001$ \\
\hline$(\mathrm{mg} / 100 \mathrm{~g})$ & $10 \mathrm{Oct}$ & 28.78 & 27.11 & 22.48 & 23.73 & 0.149 & $<0.001$ & 0.001 & 0.002 & 0.012 & 0.265 & \\
\hline $\mathrm{Gal}+\mathrm{Man} / \mathrm{Xyl}+\mathrm{Ara}^{2}$ & 16 Apr & 0.84 & 0.75 & 0.71 & 0.63 & 0.001 & $<0.001$ & $<0.001$ & 0.041 & $<0.001$ & $0.003\}$ & \\
\hline & $10 \mathrm{ot}$ & 0.76 & 0.72 & 0.72 & 0.66 & 0.024 & 0.024 & $<0.001$ & 1.000 & 0.010 & 0.010 & 0.004 \\
\hline
\end{tabular}

${ }^{1} \mathrm{E}=$ exclosure; grazing treatment: $\mathrm{L}=$ light; $\mathrm{H}=$ heavy; $\mathrm{VH}=$ very heavy.

${ }^{2} \mathrm{Gal}=$ Galaciose; Man = Mannose; Xyl = Xylose; Ara = Arabinose. 
$\mathrm{NO}_{3}{ }^{-}-\mathrm{N}$ reduces cell multiplication (Bosemark 1954; Dormaar and Ketcheson 1960; Callot et al. 1982). Although many forces interact in the field, it should be noted that root mat, and thus ramified root mass, and $\mathrm{NH}_{4}{ }^{+}-\mathrm{N}$ content decreased with increasing grazing pressure in the spring. Conversely, $\mathrm{NO}_{3}{ }^{-}-\mathrm{N}$ increased both in spring and autumn. An increased urine load can be expected to increase $\mathrm{NH}_{4}{ }^{+}-\mathrm{N}$ in the autumn. The increased urine load also manifested itself in increased $\mathrm{Na}$ and $\mathrm{K}$ on the exchange complex.

The effects of grazing per se on monosaccharide content may not be the single cause. Nevertheless, overgrazing reduced the amount of monosaccharide and thus a potential energy source in the soil. This would then lead to reduced microbial activity in the soil. The change in the galactose + mannose to xylose + arabinose ratio with increased grazing pressure, indicative of decreased microbially originated monosaccharides, supports this hypothesis.

Standing vegetation was sampled at 3 sites on the first of October to determine nutrient content of forage (Dormaar, unpublished data). As grazing pressure increased from light to very heavy, tissue concentrations of $P$ increased from 0.042 to $0.130 \%, \mathrm{~K}$ from 0.296 to $0.845 \%$, Ca from 0.403 to $0.565 \%$, and $\mathrm{Mg}$ from 0.069 to $0.123 \%$. The values for the control paddock were between those of the heavily and very heavily grazed paddocks for $\mathbf{P}$ and $K$, but were less than those for the lightly grazed samples for $\mathrm{Ca}$ and $\mathrm{Mg}$. It has been shown (Clarke and Tisdale 1945; Johnston and Bezeau 1962) that with advancing maturity of rough fescue, percent $\mathrm{Ca}$ either remained the same or increased, while percent $P$ decreased. The increased $P$ uptake is most likely related to the increased $\mathbf{N}$ content of the soil (Dormaar and Ketcheson 1960). Taking the values for available forage $\left(\mathrm{kg} \mathrm{ha}^{-1}\right)$ as presented for the lightly $(2,199)$, heavily $(1,865)$ and very heavily $(1,170)$ grazed paddocks published by Dormaar and Willms (1990), more $P$ and $K$ are removed from the very heavily than from the lightly grazed paddocks, while the reverse holds true for $\mathrm{Ca}$ and $\mathrm{Mg}$.

Mature cattle produce an average of $25 \mathrm{~kg}$ of feces plus $9 \mathrm{~kg}$ of urine per animal daily. On the average, fresh cattle feces contain $0.18 \% \mathrm{P}_{2} \mathrm{O}_{5}$, while fresh cattle urine contains approximately $0.01 \% \mathrm{P}_{2} \mathrm{O}_{5}$ (Petersen et al. 1956). While these figures are certainly not fully applicable to the present study, and, except for the heavily grazed paddock, the animal wastes are not distributed uniformly, they nevertheless allow an estimate of $P$ accumulation from cattle over a six-month period. With this caveat in place, annual $P$ additions for the light, heavy, and very heavy grazed paddocks are estimated at $0.71,1.53$, and $3.06 \mathrm{~kg} \mathrm{ha}^{-1}$. The $P$ added through excreta, rather than being fixed by the mineral component of the soil, generally remains in a slow-release availability mode, which, together with the increased Olsen's available $P$, led to increased $P$ content of the vegetation.

Phosphorus is the one major constituent of soil organic matter that must be supplied almost entirely from the parent material. Increased grazing pressure has had a significant effect on the $P$ content of the soil. Of course, there will be some loss of $P$ in animal tissue. However, since bare ground increased from zero to $15 \%$ on the very heavily grazed range (Naeth 1988), it is suspected that most of the P loss is due to sheet and wind erosion. This loss of soil $P$ is of concern.

Treatment effects on most soil parameters were most pronounced at the two heavier grazing pressures. This suggests that stocking at 2.4 AUM ha', and greater, has resulted in transformed soil conditions for the area under study. Properties characterizing good soil quality under grazing regimes may well differ from those indicative of excellent soil quality under a cropping regime. One of the major issues in soil research is the requirement to establish and define those properties that have bellwether quality. Many of the soil parameters tested in the present study responded to grazing and after 44 years of continued grazing pressure, a number of soil characteristics have shown significant shifts and, therefore, may be useful indices of soil quality.

Although we have data for time of recovery of abandoned cultivated Black Chernozemic soils (Dormaar et al. 1990b), such data are not available for abandoned overgrazed rangeland as yet. For example, what organic matter properties are able to point to shifts in potentially irreversible soil quality parameters by the end of the first summer or within the next few years when it is still possible to introduce corrective measures?

Briske and Heitschmidt (1991) noted that grazed systems are manipulated by humans to meet a diverse set of personal and/or firm-level production goals; the most pervasive of these goals is the maximization of livestock production or profitability on a sustainable basis. 'Sustainability' is considered to be the fundamental goal of rangeland management and sustainable management of rangelands depends primarily on conservation of the soil (Task Group on Unity on Concepts and Terminology Committee Members 1995).

In terms of the soil quality of the fescue grassland on which the present grazing study is being conducted, it is clear that grazing between 1.2 and $2.4 \mathrm{AUM} \mathrm{ha}^{-1}$ can be supported even though this does not lead to maximum beef production (Johnston et al. 1971; Willms et al. 1985). Nevertheless, Willms et al. (1985) reported that stocking at a light rate (1.2 AUM ha-1) for 32 years did not affect range condition, while a modest increase in stocking rate (1.6 $\mathrm{AUM} \mathrm{ha}^{-1}$ ) led already to a marked decline in range condition. Although management should not result in irreversible reductions of soil productivity (Task Group on Units in Concepts and Terminology Committee Members 1995), none of our research has ever examined recovery of grazed or perceived overgrazed rangeland. To rectify this lacuna, a recovery experiment has recently been initiated on the field that has undergone 45 years of $2.4 \mathrm{AUM} \mathrm{ha}^{-1}$ grazing pressure.

\section{Literature Cited}

Blakeney, A.B., P.J. Harris, R.J. Henry, and B.A. Stone. 1983. A simple and rapid preparation of alditol acetates for monosaccharide analysis. Carbohydr. Res. 113:291-299.

Bosemark, N.O. 1954. The influence of nitrogen on root development. Physiol. Plantarum 7:497-502.

Briske, D.D. and R.K. Heitschmidt. 1991. An ecological perspective, p.11-26. In: R.K. Heitschmidt and J.W.Stuth (eds), Grazing management: an ecological perspective. Timber Pres, Inc., Portland, Ore.

Callot, G., H. Chamayou, C. Maertens, and L. Salsac. 1982. Les interactions sol-racine.Institut Nationale de la Recherche Agronomique. Paris, France. 345 pp.

Cheshire, M.V. 1979. Nature and origin of carbohydrates in soils. Academic Press, Inc., New York, NY.

Cheshire, M.V. and C.M. Mundie. 1966. The hydrolytic extraction of carbohydrates from soil by sulphuric acid. J. Soil Sci. 17:372-381.

Clarke, S.E. and E.W. Tisdale. 1945. The chemical composition of native forage plants of southern Alberta and Saskatchewan in relation to grazing practices. Can. Dept. Agr. Tech. Bull. 54. 
Dormaar, J.F. 1984. Monosaccharides in hydrolysates of water-stable aggregates after 67 years of cropping to spring wheat as determined by capillary gas chromatography. Can. J. Soil Sci. 64:647-656.

Dormaar, J.F. and J.W. Ketcheson. 1960. The effect of nitrogen form and soil temperature on the growth and phosphorus uptake of com plants grown in the greenhouse. Can. J. Soil Sci. 40:177-184.

Dormaar, J.F. and U.J. Pittman. 1980. Decomposition of organic residues as affected by various dryland spring wheat-fallow rotations. Can. J. Soil Sci. 60:97-106.

Dormaar, J.F. and W.D. Willms. 1990. Sustainable production from the rough fescue prairie. J. Soil Water Conserv. 45:137-140.

Dormaar, J.F., S. Smoliak, and W.D. Willms. 1990a. Distribution of nitrogen fractions in grazed and ungrazed fescue grassland Ah horizons. J. Range Manage. 43:6-9.

Dormaar, J.F., S. Smoliak, and W.D. Willms. 1990b. Soil chemical properties during succession from abandoned cropland to native range. J. Range Manage. 43:260-265.

Herrick, J.E. and W.G. Whitford. 1995. Assessing the quality of rangeland soils: Challenges and opportunities. J. Soil Water Conserv. 50:237-242.

Jackson, M. L. 1958. Soil chemical analysis. Prentice-Hall, Inc., Englewood Cliffs, NJ.

Johnston, A. 1961. Comparison of highly grazed and ungrazed range in the fescue grassland of southwestern Alberta. Can. J. Plant Sci. 41:615-622

Johnston, A. and L.M. Bezeau. 1962. Chemical composition of range forage plants of the Festuca scabrella association. Can. J. Plant Sci. 42:105-115

Johnston, A., J.F. Dormaar, and S. Smoliak. 1971. Long-term grazing effects on fescue grassland soils. J. Range Manage. 24:185-188.

Keeney, D.R. and D.W. Nelson. 1982. Nitrogen-Inorganic forms. In: A.L.Page (ed), Methods of soil analysis. Part 2. Chemical and microbiological properties. Agron. 9:643-698. Amer. Soc. Agron., Madison, Wisc.
Kemper, W.D. and R.C. Rosenau. 1986. Aggregate stability and site distribution. In: A.Klute (ed), Methods of soil analysis. Part 1. Physical and mineralogical methods. Agron. 9:425-442. Amer. Soc. Agron., Madison, Wisc. Munsell Soil Color Charts. 1954. Munsell Color Co., Inc., Baltimore, Md.

Naeth, M.A. 1988. The impact of grazing on litter and hydrology in mixed prairie and fesuce grassland ecosystems of Alberta. Ph.D. Thesis, Univ. Alberta. Edmonton, AB.

Olsen, S.R., C.V. Cole, F.S. Watanabe, and L.A. Dean. 1954. Estimation of available phosphorus in soils by extraction with sodium bicarbonate. USDA, Circ. 939, U.S.Government Printing Office., Washington, DC.

Petersen, R.G., W.W. Woodhouse, Jr., and H.L. Lucas. 1956. The distribution of excreta by freely grazing cattle and its effect on pasture fertility: II. Effect of retumed excreta on the residual concentration of some fertilizer elements. Agron. J. 48:444-449.

Ridley, A.D. and R.A. Hedlin. 1968. Soil organic matter and crop yields as influenced by the frequency of summerfallowing. Can. J. Soil Sci. 48:315-322.

Simard, R.R. 1993. Ammonium acetate-extractable elements, p.39-42. In: M.R.Carter (ed), Soil sampling and methods of analysis. Lewis Publishers, Boca Raton, Fla.

Smoliak, S., J.F. Dormaar, and A. Johnston. 1972. Long-term grazing effects on Stipa- Bouteloua prairie soils. J.Range Manage. 25:246-250.

Steel, R.G.D. and J.H. Torrie. 1980. Principles and procedures of statistics. A biometric approach. 2nd ed. McGraw-Hill Book Co., Toronto, Ontario.

Task Group on Unity in Concepts and Terminology Committee Members. 1995. New concepts for assessment of rangeland condition. J.Range Manage. 48:271-282.

Willms, W.D., S. Smoliak, and J.F. Dormaar. 1985. Effects of stocking rate on a rough fescue grassland vegetation. J. Range Manage. 38:220-225.

Wroe, RA., S. Smoliak, B.W. Adams, W.D. Willms, and M.L. Anderson. 1981. Guide to range condition and stocking rates for Alberta grassiands 1988. Alberta Forestry, Lands, and Wildlife. Edmonton, AB. 